\title{
Support of ICT use in Tanzania Secondary SchoolsThe Case of Dodoma Municipality
}

\author{
Victor Crallet \\ College of Informatics and \\ Virtual Education, \\ University of Dodoma, \\ Dodoma, Tanzania
}

\author{
Abbas Ismail \\ College of Mathematical and \\ Natural Sciences, \\ University of Dodoma, \\ Dodoma, Tanzania
}

\author{
Majuto Manyilizu \\ College of Informatics and \\ Virtual Education, \\ University of Dodoma, \\ Dodoma, Tanzania
}

\begin{abstract}
Information and Communication Technology (ICT) is a tool that changes the way education operates in terms of teaching and learning. However, the analysis available for ICT facilities in schools provides stakeholders with support at those schools. This study aims at investigating the support of ICT use in Tanzania secondary schools. The findings show that Tanzania secondary schools are lagging behind at the level of application of ICT in the teaching-learning process. The ICT facilities are lacking in schools as well as the capacity for using ICT by both teachers and students is also very low. In order to fit into the new scientific order, it is necessary for Tanzania institutions and individuals alike to develop a society and culture that places a high value on information and communication technology. The government and other education stakeholder should increase funding for the entire educational sector with emphasis on using ICT. This emphasis will help improve the level of ICT facilities in the schools. There should also be continuous and periodic training of teachers on ICT skills acquisition. Such efforts will enhance support on using ICT in education resulting to socioeconomic development in the country.
\end{abstract}

\section{General Terms}

ICT, support of ICT use

\section{Keywords}

ICT, support of ICT use, ICT facilities

\section{INTRODUCTION}

Information and Communication Technology (ICT) is a tool that changes the way education is delivered as it helps teachers to organize and look for high quality lesson materials. In Tanzania, stakeholders in education and ICT sectors such as the Ministry of Education, ICT centers, Commission for Science and Technology (COSTECH) and other private and public institutions have proposed different strategies for improving learning and teaching in secondary schools using ICT (www.iicd.org). According to the International Institute for Communication and Development (IICD) among the respective areas include: improve curriculum order to simplify teaching process by using ICT demonstrations, presentations, animations; having good and effective teachers on ICT; introducing ICT aids and related materials to make teaching more effective, setting conducive teaching and learning environment and provide them with attractive monthly pay packages.

In Tanzania secondary schools, urban private schools prevail more in ICT use than government schools (Malero et al., 2015). However, in government schools, the ICT is mostly applied to secondary schools with teachers without basic ICT skills. Currently, there are ICT projects in process to address the implementation of ICT in secondary schools. In teachers college, the Government of Tanzania in collaboration with the Swedish Government through Swedish International Development Cooperation Agency (SIDA) has been carrying out a project that trains principals, tutors, and students on ICT. The training prepares ICT literate teachers to use ICT as a tool for teaching, learning, management and administration when implementing initiatives like e-school or e-learning (MoEVT, 2007).

Despite the noticeable efforts in supporting ICT use in education in Tanzania, integration issues are very common in typical educational environments. Several reasons can account for this including insufficient financial resources and overtime compensation to tutors who work overtime as well as scarcity of hardware and software resources (Swarts and Wachira, 2010). ICT tools such as blogs, discussion forums, chat rooms and social networks are quite familiar to most teachers and may be used to offer great potential for online collaboration among teachers (Ndibalema, 2014). These new tools plus facilitation from stakeholders provide a channel through which teachers can enrich themselves to strengthen the learning environments (Smith and Doyle, 2002). Since ICT tools can enhance greatly the level of education, then the purpose of this study is to examine the level of ICT use and availability of ICT facilities in secondary schools. Also the research intends to investigate the constraints for using ICT in secondary schools and if there is relationship between ICT use and availability of facilities in Tanzania with a case study in Dodoma municipality.

The following research questions were raised to guide this study:

i. To what extent are the ICT facilities available for teaching?

ii. To what extent are teachers exposed to ICT?

iii. What are the perceived constraints for using ICT?

iv. Is there any relationship between ICT use and facilitation or availability of facilities?

The introductory section (Section 1) is followed by methodology (Section 2) and results and discussion in Section 3. The paper ends with conclusion (Section 4) and recommendation part (Section 5).

\section{METHODOLOGY}

\subsection{Study Design, Data and Sampling}

The descriptive survey design was used for this study. The population for the study consisted of all the teachers and 
headmasters of the secondary schools in Dodoma. The sample for the study is made up of 231 teachers including headmasters randomly selected from 16 secondary schools in Dodoma municipality.

A structured questionnaire was used to collect the data for the study. The questionnaire was administered to respondents with the help of researchers in the schools visited. Personal contacts of the researchers with the respondents enhanced good and prompt response from the respondents.

Information gathered involved the use of ICT tool in delivering content, ICT support from the education stakeholders, readiness to use ICT, ICT training and classes in addition to software applied by teachers in teaching process. Also major factors for ICT enabled environment like availability of electricity, computer lab, internet connectivity and electronic systems for student registration, examination results were considered.

\subsection{Study variables}

During the analysis, the outcome variable was taken to be the number of teachers who use ICT skills and the independent variables were to support related variables like type of support, source of support, reasons for not using ICT, ICT training, existence of ICT classes, software used in teaching process, internet facility, and computer labs.

\subsection{Methods of data analysis}

Data collected during the study were analyzed using frequency counts and percentage scores for obtaining information about availability of ICT facilities, extent of ICT use and perceived constraints of using ICT. According to Cone and Foster (2005), correlation analysis can be used to investigate the relationship between variables. Therefore, a Pearson product-moment correlation coefficient was used to find whether there was any significant relationship between ICT uses and availability of facilities (Lazarus et al., 2013).

\section{RESULTS AND DISCUSSION}

\subsection{Results}

The results of the study are presented below:

Research question 1: To what extent are the ICT facilities available for teaching?

Table 1 show that electricity is available in most schools while about $30.8 \%$ of the schools are equipped with computer laboratories. Some facilities like projectors, computers, internet, and e-books seemed to be rarely available. However, there was a tendency for schools to incorporate computers for only administrative purposes.

Research question 2: To what extent are teachers exposed to ICT?

Table 2 shows the extent to which the teachers are exposed to the use of ICT facilities in secondary schools. Only 35.5\% of the teachers agreed that they use the internet to search for teaching materials, while about $20.8 \%$ of them agreed that they have attended courses related to ICT integration in teaching and learning. About 55.8\% of the respondents also agreed that they have attended a basic ICT course. Of the respondents, $39 \%$ agreed that teachers use internet and email in teaching and learning processes, while 26.4, 32.9, 5.6 and $6.5 \%$ agreed that they are using spreadsheets, word processors, databases and desktop publishing, respectively. On the average $25.2 \%$ of the respondents agreed that teachers were exposed to the use of ICT. Such results imply that teachers are less exposed to the use of ICT.

Research question 3: What are the perceived constraints for using ICT?

From Table 3, it is shown that the major obstacle facing the use of ICT in Dodoma municipality secondary schools is the fact that many teachers don't get support from school, municipal, ministry or any other government body (61.3\%).

Table 1: Extent of ICT facilities availability for teaching in secondary schools in Dodoma municipality

\begin{tabular}{clcccc}
\hline S/N & \multicolumn{1}{c}{ ITEM } & AVAILABLE & $\%$ & NOT AVAILABLE & $\%$ \\
\hline 1 & Electricity & 182 & 78.6 & 49 & 21.4 \\
2 & Computer lab & 71 & 30.8 & 160 & 69.2 \\
3 & E-books & 21 & 9.1 & 210 & 90.9 \\
4 & Internet & 58 & 25 & 173 & 75 \\
5 & ICT classes & 36 & 15.4 & 195 & 84.6 \\
6 & Computer for administration & 149 & 64.3 & 82 & 35.7 \\
7 & Computer for registration and examination results & 39 & 16.7 & 192 & 83.3 \\
& Preparation & & & & \\
8 & Projector & 16 & 6.9 & 215 & 93.1 \\
9 & Computer & 36 & 15.6 & 195 & 84.4 \\
\hline
\end{tabular}


Table 2: Exposure of teachers to the use of ICT in secondary schools in Dodoma municipality

\begin{tabular}{|c|c|c|c|c|c|}
\hline $\mathrm{S} / \mathrm{N}$ & ITEM & AGREE & $\%$ & DISAGREE & $\%$ \\
\hline 1 & Do you use the internet to search for teaching materials? & 82 & 35.5 & 149 & 64.5 \\
\hline 2 & Have you attended any ICT basic course? & 129 & 55.8 & 102 & 44.2 \\
\hline 3 & Have you attended a course in web design / multimedia / programming? & 10 & 4.3 & 221 & 95.7 \\
\hline 4 & $\begin{array}{l}\text { Have you attended courses related to ICT integration in teaching and } \\
\text { learning? }\end{array}$ & 48 & 20.8 & 183 & 79.2 \\
\hline 5 & Do you use spreadsheets in your teaching and learning processes? & 61 & 26.4 & 170 & 73.6 \\
\hline 6 & Do you use word processors in your teaching and learning processes? & 76 & 32.9 & 155 & 67.1 \\
\hline 7 & Do you use databases in your teaching and learning processes? & 13 & 5.6 & 218 & 94.4 \\
\hline 8 & Do you use desktop publishing in your teaching and learning processes? & 15 & 6.5 & 216 & 93.5 \\
\hline 9 & Do you use internet and email in your teaching and learning processes? & 90 & 39 & 141 & 61 \\
\hline & Mean & & 25.2 & & 74.8 \\
\hline
\end{tabular}

Table 3: Perceived constraints for using ICT in secondary schools in Dodoma municipality

\begin{tabular}{clcccc}
\hline S/N & ITEM & AGREE & $\%$ & DISAGREE & $\%$ \\
\hline 1 & Support from school/municipal/ministry or any other government body? & 89 & 38.7 & 142 & 61.3 \\
2 & Support from my employer & 190 & 82.3 & 41 & 17.7 \\
3 & Motivated & 224 & 97 & 7 & 3 \\
4 & There are ICT infrastructure set up for the school & 136 & 58.9 & 95 & 41.1 \\
5 & Have the required skills and knowledge & 213 & 92.2 & 18 & 7.8 \\
\hline & Mean & & 73.8 & & \\
\end{tabular}

Research question 4: Is there any relationship between ICT use and availability of facilities?

Using the Pearson correlation statistical analysis for a 0.05 level 2-tailed significance test is used. It is observed that teachers' level of ICT use at the secondary schools in Dodoma municipality is positively linked to the availability of electricity, e-books and electronic systems for students' registration, examination results as reported by the school headmasters/headmistresses, and this is shown in Table 4.

\subsection{Discussion}

This study revealed that ICT facilities such as computer laboratories, e-books, internet, projectors and computers were not available in secondary schools in Dodoma municipality. This could be attributed to inadequate funding of the schools by the government and stakeholders. This finding has a major consequence on the competence of the teachers. Even if the teachers are willing to learn and use ICT, unavailability of the facilities will be a constraint to them.

The study also revealed that teachers were exposed to the use of ICT to a little extent. This is a source of the low level of ICT application in teaching and learning in secondary schools.
The implication is that most of the teachers are still using the old method of chalk and talk, the practice which makes them to be behind the world of ICT.

Furthermore, it was revealed that the most perceived constraints of using ICT in schools is the fact that many teachers don't get support from school, municipal, ministry or any other government body. Therefore support from school, municipal, ministry or any other government body is the major challenge facing the application of ICT in secondary schools in Dodoma municipality. This is attributed to low level of funding in the school system from stakeholders. If schools are well funded, the management of the school can always make arrangements for ICT practices. 
Table 4: Relationship between availability of ICT facilitation and ICT use in secondary schools in Dodoma municipality

\begin{tabular}{|c|c|c|c|}
\hline \multirow[b]{2}{*}{ Availability of ICT Facilitation } & & \multicolumn{2}{|c|}{ ICT Use } \\
\hline & & Spreadsheets & Word Processors \\
\hline Electricity & $\begin{array}{l}\text { Pearson Correlation } \\
\text { Sig. (2-tailed) } \\
\mathrm{N}\end{array}$ & $\begin{array}{r}.516 \\
.086 \\
12 \\
\end{array}$ & $\begin{array}{r}.354 \\
.437 \\
7 \\
\end{array}$ \\
\hline Computer laboratory & $\begin{array}{l}\text { Pearson Correlation } \\
\text { Sig. (2-tailed) } \\
\mathrm{N}\end{array}$ & $\begin{array}{r}.106 \\
.757 \\
11\end{array}$ & $\begin{array}{r}.091 \\
.846 \\
7\end{array}$ \\
\hline E-books & $\begin{array}{l}\text { Pearson Correlation } \\
\text { Sig. (2-tailed) } \\
\mathrm{N}\end{array}$ & $\begin{array}{r}.303 \\
.428 \\
9\end{array}$ & $\begin{array}{r}.447 \\
.374 \\
6\end{array}$ \\
\hline Internet facility & $\begin{array}{l}\text { Pearson Correlation } \\
\text { Sig. (2-tailed) } \\
\mathrm{N}\end{array}$ & $\begin{array}{r}.378 \\
.282 \\
10\end{array}$ & $\begin{array}{r}-.500 \\
.312 \\
6\end{array}$ \\
\hline Computer for administrative use & $\begin{array}{l}\text { Pearson Correlation } \\
\text { Sig. (2-tailed) } \\
\mathrm{N}\end{array}$ & $\begin{array}{r}.193 \\
.548 \\
12\end{array}$ & $\begin{array}{r}.167 \\
.721 \\
7\end{array}$ \\
\hline $\begin{array}{l}\text { Electronic system for students' } \\
\text { registration, exam results, }\end{array}$ & $\begin{array}{l}\text { Pearson Correlation } \\
\text { Sig. (2-tailed) } \\
\mathrm{N}\end{array}$ & $\begin{array}{r}.297 \\
.405 \\
10\end{array}$ & $\begin{array}{r}.447 \\
.374 \\
6\end{array}$ \\
\hline Class teaching ICT classes & $\begin{array}{l}\text { Pearson Correlation } \\
\text { Sig. (2-tailed) } \\
\mathrm{N} \\
\end{array}$ & $\begin{array}{r}.219 \\
.518 \\
11 \\
\end{array}$ & $\begin{array}{r}-.113 \\
.809 \\
7 \\
\end{array}$ \\
\hline
\end{tabular}

*. Correlation is significant at the 0.05 level (2-tailed).

\section{CONCLUSION}

The finding of this study has shown that Tanzania secondary schools are far behind when it comes to application of ICT in the teaching-learning process. There is a scarcity of ICT facilities in schools; the ability of using ICT by teachers and students is also very low. Despite the benefits of using ICT in school, there are a lot of barriers for the successful application of ICT in secondary schools. It is essential for Tanzania institutions and individuals to develop a society and culture that gives a high value on Information and Communication Technology in order to fit into the new scientific order,

\section{RECOMMENDATIONS}

The following recommendations are therefore in order. The government and other education stakeholder should increase funding for the entire educational system with more emphasis on using ICT. This will promote the level of ICT facilities in the schools to a new domain. Also ICT skills acquisition programmes should be initiated for teachers on. Such programmes will provide teachers with practical and functional knowledge of the computer. ICT skills acquisition trainings will help teachers to learn or update their knowledge on the internet and associated areas of ICT. Such knowledge and practices will improve the teaching and learning environment in secondary schools in Tanzania leading to economic, technological and social growth.

\section{ACKNOWLEDGEMENT}

Special thanks to the Carnegie-SIG Regional Initiative in Science and Education (RISE) through its competitive fund award for supporting this research. Furthermore, the authors thank to Computation and Modelling Research Group at University of Dodoma for the support on technical and academic issues regarding this publication. Moreover, this study wouldn't have been possible without a generous support from headmasters, headmistress and teachers of secondary schools in Dodoma municipality.

\section{REFERENCES}

[1] A. Malero, A. Ismail and M. Manyilizu. "ICT Usage Readiness for Private and Public Secondary Schools in Tanzania, a case of Dodoma Municipality", International Journal of Computer Applications, Volume 130, November 2015.

[2] MoEVT. 2007. Information and Communication Technology (ICT). Policy For Basic Education. United Republic of Tanzania, Ministry of Education and Vocational Training (MoEVT).

[3] P. Swarts and E.M. Wachira. 2010. Tanzania: ICT In Education Situational Analysis. Report. Global e-Schools and Communities Initiatives. 
[4] P. Ndibalema, "Teachers Attitudes towards the Use of ICT as a Pedagogical Tool in Secondary Schools in Tanzania: The Case of Kondoa District", International Journal of Education and Research, Volume 2, February 2014.

[5] M. K. Smith and M. E. Doyle, " Globalization: theory and experience", International Journal of Education and Development using Information and Communication Technology (IJEDICT), 2002.
[6] J. D. Cone and S. L. Foster. 2005. Dissertations and theses from start to finish. Washington DC: American Psychological Association.

[7] L. Makewa, "ICT in secondary school administration in rural southern Kenya: An educator's eye on its importance and use", International Journal of Education and Development using Information and Communication Technology (IJEDICT), Volume 9, 2013 